\title{
Kepemimpinan, Pengambilan Keputusan dan Diskresi
}

\author{
Jetty Erna Hilda Mokat \\ UNIMA \\ Tondano, Indonesia \\ jettymokat@yahoo.co.id
}

\begin{abstract}
Abstrak- Penelitin ini bertujuan untuk menganalisis dan mendeskripsikan proses pengambilan keputusan pemimpin pada Fakultas Ilmu Sosial Universitas Negeri Manado (Unima). Pendekatan penelitian yang digunakan adalah deskriptif kualitatif dengan tehnik pengumpulan data ditempuh melalui observasi, wawancara mendalam dan dokumentasi. Sumber data penelitian meliputi sumber data primer yang diperoleh dari informan secara purposive sampling, yang didukung dengan data sekunder berupa studi kepustakaan, regulasi terkait dan dokumen pendukung lainnya. Hasil penelitian menunjukkan bahwa proses pengambilan keputusan pemimpin (Dekan) ditempuh melalui enam tahapan, yang meliputi: 1) tahapan mengidentifikasi dan menganalisis permasalahan; 2) mengidentifikasi alternatif-alternatif dan solusi pemecahan masalah; 3) menganalisis dan mengevaluasi masing-masing alternatif solusi; 4) memilih alternatif terbaik; 5) melaksanakan keputusan; dan 6) melakukan evaluasi. Untuk mengatasi stagnasi dan dalam rangka kelancaran pelaksanaan tugas dan fungsinya, maka dekan sebagai pemimpin organisasi melakukan tindakan diskresi untuk kepentingan publik sebagai solusi terhadap berbagai permasalahan yang dihadapi dalam rangka menjawab tuntutan dan ekspektasi masyarakat/mahasiswa.
\end{abstract}

Kata Kunci: Kepemimpinan, Pengambilan Keputusan, Tindakan Diskresi.

\section{PENDAHULUAN}

Pengambilan keputusan merupakan salah satu elemen penting yang tidak terpisahkan dari kepemimpinan, apalagi dalam aktivitasnya pemimpin dipenuhi dengan tugas-tugas terkait dengan pengambilan keputusan. Pengambilan keputusan adalah suatu tindakan yang dilakukan seorang pemimpin untuk memilih dari sekian alternatif pilihan yang tersedia sebagai upaya memecahkan permasalahan yang dihadapi dalam rangka mencapai tujuan. Oleh sebab itu dapat dikatakan bahwa pengambilan keputusan sebagai kegiatan sentral manajemen, dan merupakan kunci dari kepemimpinan. Apalagi pengambilan keputusan tidak hanya dilakukan oleh pemimpin tingkatan paling tinggi, tetapi juga pada tingkatan paling bawah dari suatu organisasi.

Begitu pentingnya pengambilan keputusan bagi kemajuan organisasi dapat dilihat pada setiap tahapan manajemen, yaitu mulai dari tahap perencanaan sampai dengan tahapan evaluasi, pengambilan keputusan diperlukan. Bagaimanapun baiknya kinerja individu pada akhirnya akan berpengaruh pada efektivitas dan kinerja organisasi. Pemimpin, kepemimpinan dan pengambilan keputusan merupakan dimensi yang saling berhubungan dan turut menentukan keberhasilan organisasi apapun bentuk organisasinya, organisasi pemerintah ataupun swasta. Hal ini menunjukkan bahwa seorang pemimpin memiliki peranan dan fungsi yang sangat menentukan bagi pencapaian tujuan organisasi. Bahkan Wirawan menegaskan bahwa fungsi utama pemimpin adalah menentukan visi, misi, strategi dan tujuan sistem sosial dan membuat keputusan. Dan untuk menentukan visi, misi, strategi dan tujuan juga dilakukan melalui proses membuat keputusan (Wirawan, 2013: 651). Hasil keputusan inilah yang diterapkan pada kinerja organisasi untuk memperoleh hasil yang diharapkan.

Kepemimpinan yang kuat akan muncul apabila sistem kepemimpinan mampu menghasilkan kinerja yang tinggi, sinergi, dan berkualitas. 
Kualitas kepemimpinan seseorang menentukan kuat tidaknya, berhasil tidaknya serta mampu atau tidak seorang pemimpin mempengaruhi individuindividu yang ada dalam organisasi yang dipimpinnya. Seorang pemimpin melaksanakan tugas dan aktivitas yang menjadi tanggungjawabnya sesuai dengan arah dan tujuan yang sudah ditetapkan. Berdasarkan arah dan tujuan tersebut seorang pemimpin mengambil keputusan, sehingga tidak berlebihan bila dikatakan bahwa kehadiran seorang pemimpin dalam organisasi menjadi keharusan, karena pemimpin memiliki tugas dan fungsi yang sangat menentukan keberhasilan organisasi, mulai dari penentuan visi, misi bahkan strategi dalam mencapai tujuan. Oleh sebab itu Davis sebagaimana dijelaskan oleh Hicks dan Gullet bahwa "tanpa pimpinan, suatu organisasi hanya akan merupakan campur aduknya manusia dan peralatan" (Hicks dan Gullet 1987:492). Pemimpin organisasi dalam hal ini pemimpin publik sifatnya formal adalah pemimpin yang menduduki jabatan dalam organisasi formal dengan sistem hierakhi serta tugas dan wewenangnya sudah ditentukan.

Kompleksnya tugas pemimpin, maka seorang pemimpin dituntut memiliki berbagai kelebihan dan kemampuan (kecakapan, kecerdasan, keterampilan, dan semangat kerja) dibanding anggota lainnya/orang yang dipimpinnya dan mampu mengambil keputusan yang tepat, berkualitas sesuai harapan dan tujuan yang ingin dicapai organisasi. Luthans (2006: 406) berpendapat bahwa pengambilan keputusan adalah sebagai pemilihan alternatif. Demikian juga dengan Greenberg dan Baron sebagaimana dijelaskan Sunyoto dan Burhanudin (2015: 54) bahwa pengambilan keputusan sebagai proses menentukan pilihan dari berbagai alternatif. Hal ini berarti bahwa aktivitas seorang pemimpin dalam pengambilan keputusan untuk menentukan pilihan, sangat terkait dengan kemampuan yang dimilikinya sehingga berpengaruh pada kualitas dan kinerja organisasi yang pada akhirnya berdampak pada keberhasilan serta masa depan organisasi. Dampak yang ditimbulkan dari keputusan seorang pemimpin organisasi bisa positif, tetapi juga bisa negatif. Menurut Ivancevich dkk (2007:19) "kualitas pengambilan keputusan dalam organisasi bergantung pada pemilihan tujuan yang tepat dan pengidentifikasian cara pencapaian". Bahkan menurut Simon bahwa setiap keputusan melibatkan pemilihan satu tujuan dan satu perilaku yang berhubungan dengannya; namun tujuan itu boleh jadi merupakan sarana dari suatu tujuan yang lebih jauh; dan seterusnya, sehingga tercapai tujuan akhir (Simon, 1982: 50). Berdasarkan beberapa pendapat tersebut, dapat disimpulkan bahwa pengambilan keputusan merupakan suatu proses di dalam menentukan suatu pilihan yang terbaik sebagai upaya menyelesaikan masalah dalam rangka mencapai tujuan.

Proses pengambilan keputusan menurut Herbert A. Simon meliputi tiga tahapan utama, yaitu: 1) Aktivitas Intelegensi; 2) Aktivitas Desain; dan 3) Aktivitas memilih. Selanjutnya Mintzberg menegaskan langkah pengambilan keputusan meliputi: 1) Tahap Indentifikasi; 2) Tahap Pengembangan; dan 3) Tahap seleksi (Luhtans, 2006: 406-407). Sedangkan menurut Winardi ada empat langkah proses pengambilan keputusan yang meliputi aktivitas: 1) menentukan problema yang berkaitan dengan sasaran-sasaran yang ingin dicapai; 2) mengidentifikasi pemecahan-pemecahan alternatif; 3) menganalisis hasil-hasil masing-masing alternatif; dan 4) memilih salah satu alternatif untuk diimplementasikan (Winardi, 2010: 561). Jadi pada dasarnya proses pengambilan keputusan dapat ditempuh dalam beberapa tahapan, mulai dengan melakukan penelusuran menemukan permasalahan, kemudian diidentifikasi sebelum menentukan prioritas pilihan untuk dilaksanakan dengan resiko terendah. Selanjutnya diakhiri dengan evaluasi sebagai aktivitas menilai proses dan hasil keputusan untuk mengetahui kesesuaian dengan harapan serta melakukan koreksi bila diperlukan. 
Pengambilan keputusan adalah kewenangan seorang pemimpin, yang merupakan kunci kepemimpinan di dalam mengkoordinasikan kegiatan-kegiatan dalam organisasi. Chester Barnard berpendapat bahwa kewenangan terletak pada persetujuan yang mempunyai daya kekuatan (potentiality of assent) yaitu yang tersebar luas berujud kesetiaan, kesadaran anggota tentang tujuan bersama dari pada organisasi itu. Maksudnya ialah kesetiaan dan kesadaran melaksanakan tujuan dari pada suatu program, sekalipun para pejabat yang terendah sekalipun, mempunyai kewenangan yang nyata (actual power) untuk mengambil keputusan yang terakhir dalam batas wewenangnya (Handayaningrat, 1993: 67-68). Kewenangan sangat terkait dengan kekuasaan bertindak pemimpin, dan kekuasaan merupakan sarana kepemimpinan. Dengan kekuasaan, seorang pemimpin publik diakui oleh bawahannya, karena otoritas melekat pada jabatan. Dengan otoritas, pemimpin menjadikannya acuan bertindak untuk melaksanakan kepemimpinan. Seorang pemimpin, karena jabatannya secara otomatis memiliki otoritas sehingga yang terjadi hubungan kekuasaan, karena bawahan berada di bawah garis komandonya.

Kepemimpinan dalam suatu organisasi pemerintahan diwujudkan dalam hierarkhi kewenangan sebagai kekuasaan legitimasi. Menurut Thoha (2011: 334) "kekuasaan legitimasi (legitimate power) bersumber pada jabatan yang dipegang oleh pemimpin. Secara normal, semakin tinggi posisi seorang pemimpin, maka semakin besar kekuasaan legitimasinya". Kekuasaan legitimasi dapat menyebabkan seorang pemimpin bertindak melebihi batas, atau tindakan sewenangwenang, karena jabatan. Dengan otoritas yang melekat pada pada jabatan tersebut menyebabkan seorang pemimpin merasa bahwa ia mempunyai wewenang dan mengandalkan kekuasaan sebagai alasan untuk mempengaruhi bawahannya sehingga lebih mengarah pada paksaan dari pada pengaruh.
Otoritas diperlukan dalam suatu organisasi terutama dalam melaksanakan tugas dan fungsinya. Agar pelaksanaan tugas dan fungsi pemerintah terlaksana secara efektif, maka kepada pemerintah diberi kewenangan diskresi sebagai konsekuensi logis dalam mengantisipasi meningkatnya kebutuhan hidup manusia dan perkembangan yang ada. Tindakan diskresi ini dapat dibenarkan, mengingat keberadaan diskresi diperlukan utamanya untuk melengkapi kekurangan dari prinsip legalitas. Namun demikian, dalam realisasinya penggunaan diskresi dengan alasan untuk kepentingan banyak orang justru mengorbankan banyak orang karena kurang sesuai dengan maksud dan tujuannya yang menyebabkan terjadi pelanggaran.

Diskresi merupakan salah satu cara yang ditempuh untuk menyelesaikan permasalahan tertentu yang tidak/belum diatur dengan aturan yang baku, untuk mencari solusi terhadap berbagai permasalahan yang dihadapi pemerintah dalam menjawab tuntutan dan ekspektasi masyarakat. Dalam UURI Nomor 30 Tahun 2014 tentang Administrasi Pemerintahan pasal 22 ayat (1) ditegaskan bahwa diskresi hanya dapat dilakukan oleh pejabat pemerintahan yang berwenang. Ayat (2) Setiap penggunaan diskresi pejabat pemerintahan bertujuan untuk: a). melancarkan penyelenggaraan pemerintahan; $b$. mengisi kekosongan hukum; c. memberikan kepastian hukum; dan d. mengatasi stagnasi pemerintahan dalam keadaaan tertentu guna kemanfaatan dan kepentingan umum.

Pada kenyataannya banyak pemimpin yang salah mengambil tindakan diskresi yang berakibat pada penyalahgunaan wewenang. Akibatnya kewenangan diskresi berpotensi menimbulkan dampak negatif yang merugikan masyarakat. Seyogyanya diskresi dimaksudkan untuk mengatasi stagnasi dalam pemerintahan, dan untuk kepentingan umum yang mendesak utamanya untuk menyelesaikan permasalahan yang timbul dan belum ada aturannya atau belum diatur tetapi membutuhkan penyelesaikan sesegera mungkin dalam rangka peningkatan 
kualitas pelayanan publik. Banyak upaya telah dilakukan pemerintah untuk meningkatkan kualitas pelayanan publik, namun tidak dapat disangkal bahwa upaya ini masih menyisakan cerita sebaliknya. Diskresi yang memberi ruang gerak lebih besar kepada pemerintah, ternyata belum mampu menyelesaikan persoalan yang terjadi dalam mengelola organisasi pemerintahan sesuai harapan. Walaupun ada yang berhasil memanfaatkan kewenangan yang dimilikinya untuk memperbaharui manajemen pelayanan publik, tetapi tidak sedikit yang gagal menjalankan tugas dan fungsinya.

Berbagai permasalahan masih ditemui pada organisasi pemerintahan, antara lain terkait keputusan yang dipandang kurang sesuai dengan yang sudah ditetapkan semula, keputusan dianggap kurang berkualitas, kurang mampu menyelesaikan persoalan, otonomi yang tidak diikuti dengan reformasi birokrasi dan pelayanan publik yang baik, serta kepemimpinan yang lebih cenderung berorientasi pada kepentingan pribadi dan kelompok.

Pemimpin organisasi perguruan tinggi dalam menjalankan dan melaksanakan kebijakan pasti diperhadapkan dengan aktivitas mengambil keputusan yang sifatnya memberikan akomodasi bagi kepentingan banyak orang utamanya untuk kepentingan mahasiswa. Dan pimpinan fakultas adalah pejabat yang diberi ruang gerak yang longgar untuk menata penyelenggaraan tugasnya agar tetap berada pada koridor perundangan yang berlaku dan diimbangi dengan akuntabilitas publik. Hanya saja bagaimana memanfaatkannya agar berfungsi secara maksimal serta dapat mengatasi dan menyelesaikan permasalahan konkret yang dihadapi sehingga dapat dipertanggungjawabkan.

Sehubungan dengan uraian sebelumnya, pimpinan di Universitas` Negeri Manado UNIMA lebih khusus Fakultas Ilmu Sosial (FIS) sebagai lembaga publik yang bergerak di bidang pendidikan berupaya melaksanakan tugas dan fungsinya untuk meningkatkan kualitas pelayanannya. Walaupun harus diakui bahwa kualitas pelayanan belum memberikan hasil yang maksimal, tetapi upaya ke arah itu terus dilakukan. Fasilitas yang belum memadai menjadi salah satu alasan tidak/kurang optimalnya pelayanan utamanya pelayanan akademik. Kegiatan yang dilakukan hanyalah tugas-tugas rutin administratif yang kurang mengarah pada upaya untuk melakukan reformasi pelayanan yang sebenarnya menjadi keharusan guna efektivitas dan efisiensi pelayanan publik. Di samping, masih banyaknya keluhan-keluhan dari penerima layanan dalam hal ini mahasiswa terkait dengan pelayanan yang dianggap kurang berkualitas. Sebagaimana empirical problem terkait pengambilan keputusan seorang pemimpin antara lain: hasil keputusan tidak/kurang sesuai dengan yang ditetapkan, proses pengambilan keputusan dipandang kurang mengikuti prosedur, penggunaan diskresi oleh pimpinan dengan alasan untuk kepentingan banyak orang tetapi mengorbankan orang lain karena terjadi pergeseran rencana kegiatan, sehingga terkesan perencanaan yang kurang matang, dan kurang profesional.

\section{METODE PENELITIAN}

Penelitian ini menggunakan metode kualitatif, bertujuan mendeskripsikan dan menganalisis pengambilan keputusan pemimpin pada Fakultas Ilmu Sosial (FIS) Universitas Negeri Manado, yang difokuskan pada proses pengambilan keputusan. Sumber data dalam penelitian ini meliputi sumber data primer dan sekunder. Sumber data primer diperoleh dari informan melalui wawancara mendalam kepada informan yang telah ditentukan (purposive sampling), yang meliputi: Kepala Bagian, Kepala Sub Bagian, Pegawai, Pimpinan Jurusan/ Program Studi, Dosen, Pembantu Dekan, dan Dekan sebagai konfirmator. Penelitian ini juga didukung dengan data-data sekunder seperti studi kepustakaan, peraturan perundangan dan dokumen pendukung lainnya yang relevan dengan penelitian ini. Sedangkan data yang terkumpul dilakukan pengecekan melalui proses triangulasi. Teknik 
analisis data meliputi komponen: reduksi data, penyajian data, dan verifikasi data menurut Miles dan Huberman (2007).

\section{HASIL DAN PEMBAHASAN}

Sesuai permasalahan penelitian, maka penelitian ini mengkaji proses pengambilan keputusan pemimpin dan mengaplikasikan dengan teori sebagai pendukung dalam mengkaji permasalahan.

\section{A. Proses Pengambilan Keputusan}

Kehidupan seorang pemimpin dipenuhi dengan serangkaian aktivitas pengambilan keputusan yang memainkan peranan sangat penting ketika pemimpin menjlankan tugas dan fungsinya. Melalui pengambilan keputusan akan nampak serangkaian kegiatan yang dipilih dalam penyelesaian suatu masalah. Untuk efektifnya pengambulan keputusan, maka salah satu aspek penting yang perlu diperhatikan adalah bagaimana prosesnya. Dalam penjelasan terdahulu, ada berbagai pendapat ahli terkait dengan proses pengambilan keputusan.

Menurut Luthans (2006: 406) bahwa pengambilan keputusan adalah "sebagai pemilihan alternatif", bahkan menurut Ivancevich sebagaimana dijelaskan Djatmiko (2008: 75) bahwa pengambilan keputusan "berpengaruh kuat secara langsung terhadap kinerja individu". Manusia secara pribadi maupun kelompok dipastikan tidak akan lepas dari aktivitas mengambil keputusan, utamanya dalam kapasitas sebagai pemimpin organisasi pemerintahan termasuk di dalammnya dilingkungan perguruan tinggi. Pemimpin organisasi pemerintahan senantiasa diperhadapkan dengan berbagai kebijakan dimana pemimpin/pejabat atau birokrat memiliki kewenangan bukan saja menetapkan kebijakan, tetapi juga mengambil keputusan. Bahkan aktivitas terkait dengan pengambilan keputusan sudah dimulai dari tahapan mengidentifikasi dan menganalisis problem sampai pada tahapan implementasi dan evaluasi hasil keputusan.

Berdasarkan data temuan penelitian menunjukkan bahwa dekan mengambil keputusan berdasarkan tahapan-tahapan dalam proses pengambilan keputusan, yaitu: 1) tahapan identifikasi dan analisis problem, yaitu pemimpin dalam hal ini mengidentifikasi dan mengenal problem serta mengumpulkan data, menelusuri dan mengenal permasalahan yang ada, serta mengidentifikasi penyebab terjadinya masalah; 2) Mengidentifikasi dan menganalisis alternatif solusi (tahapan mengumpulkan sebanyak banyaknya alternatif solusi permasalahan untuk mencari alternatif dan merumuskan solusinya); 3) Mengevaluasi alternatif-alternatif terbaik (tahapan memilih satu alternatif yang dianggap paling baik dari alternatif-alternatif yang tersedia); 4) Melaksanakan keputusan, dan 5) Mengevaluasi hasil keputusan.

Tahapan-tahapan tersebut diawali dengan proses penelusuran untuk mengetahui berbagai permasalahan yang ada pada bidang pendidikan dan pengajaran, administrasi dan keuangan, serta kemahasiswaan. Permasalahan-permasalahan yang diperoleh diidentifikasi berdasarkan jenis permasalahan. Mengidentifikasi permasalahan merupakan bagian yang sangat penting dilakukan untuk mengetahui hubungan sebab-akibatnya. Keadaan ini bukan hal yang mudah, karena membutuhkan ketelitian sehingga perlu melibatkan berbagai pihak dan membahas secara bersama.

Permasalahan yang sudah teridentifikasi diteliti, dikaji untuk mengetahui bentuk dan sifat permasalahan serta bagaimana penyelesaiannya. Untuk itu dibutuhkan data dan informasi yang cukup. Pada tahapan ini kadang pemimpin tidak mendapatkan data yang dibutuhkan, sehingga sulit merumuskan masalah dan penyelesaiannya. Kurang lengkapnya data dan informasi mengharuskan pemimpin membuat keputusan 
memilih salah satu di antara alternatif pilihan yang ada walaupun tidak ideal, tetapi dengan resiko yang kecil.

Tahapan selanjutnya membuat keputusan berdasarkan alternatif pilihan yang terbaik untuk diimplementasikan dengan membuat rencanarencana dengan mempertimbangkan kemungkinan yang muncul dalam pelaksanaan keputusan beserta resiko sebagai konsekuensi dari keputusan serta bagaimana penanggulangannya. Permasalahan yang sudah teridentifikasi dianalisis untuk merumuskan alternatif solusinya, agar dapat menentukan alternatif yang dianggap paling baik. Berdasarkan alternatif-alternatif pilihan tersebut, maka keputusan diambil untuk dilaksanakan. Untuk mengetahui efektivitas alternatif-alternatif tersebut maka perlu dievaluasi agar dapat diketahui efektivitas masing-masing alternatif dalam memecahkan permasalahan.

Tahapan berikutnya adalah evaluasi untuk menilai proses dan hasil implementasi keputusan. Melalui evaluasi ini dapat diketahui solusi yang tepat dan efektif agar dapat melakukan koreksi dalam rangka revisi terhadap berbagai kelemahan. Adapun tujuan evaluasi untuk menilai efektivitas solusi. Jika solusi tersebut efektif maka akan mengurangi kesenjangan/gap antara kenyataan yang terjadi dengan apa yang diharapkan" (Sunyoto dan Burhanudin, 2015: 57). Jadi revisi dapat dilakukan berdasarkan alternatif pilihan yang sudah ditentukan setelah diketahui kelemahanya.

Berdasarkan data dan hasil penelitian dapat diketahui bahwa pada dasarnya permasalahan seringkali muncul karena ada kebijakan dari pimpinan tingkat lebih tinggi (Universitas) sehingga mengharuskan pimpinan Fakultas mengambil langkah bagaimana menghadapi tantangan dan menanggulangi permasalahan yang muncul akibat perubahan kebijakan dan atau adanya kebijakan baru. Sinyalimen keadaan ini terjadi karena perencanaan yang kurang matang, dan kurang melibatkan Jurusan dan Program Studi dalam pembahasan rencana dan program kerja. Untuk mengantisipasi kesalahan penentuan solusi terhadap permasalahan, maka diadakan rapat pimpinan di tingkat Fakultas dan dilanjutkan dalam rapat periodik yang dihadiri oleh dosen dan pegawai, dengan maksud untuk mendapatkan solusi terbaik berdasarkan masukan dari peserta rapat. Ada permasalahan yang membutuhkan penanganan sesegera mungkin, tetapi ada juga permasalahan yang penyelesaiannya dapat ditunda atau ditangguhkan sementara sehingga pemimpin perlu menetapkan skala prioritasnya.

Setiap pemimpin organisasi/institusi publik perlu merespons setiap permasalahan terkait dengan kebutuhan yang terjadi dan berkembang dalam organisasi agar terbangun hubungan yang interaktif antara pemimpin dengan yang dipimpin. Kebutuhan dan tuntutan masyarakat organisasi yang serba kompleks membutuhkan pendekatan yang rasional dalam menentukan prioritas. Dengan demikian pemimpin sedapat mungkin mengambil langkah yang mendekati rasional. Pilihan rasional adalah pilihan yang dapat diterima secara rasio oleh banyak orang. Melalui kemampuan pengambilan keputusan inilah kompetensi dan kapabilitas pemimpin diuji. Keputusan pemimpin menentukan kualitas dan masa depan organisasi yang dipimpinnya. Dan proses pengambilan keputusan merupakan kegiatan di dalam pemilihan tindakan dari sejumlah alternatif yang ada, kemudian alternatifalternatif tersebut dievaluasi dan diseleksi dengan mempertimbangkan kelemahan dan kebaikannya bagi organisasi. Alternatif yang paling tinggi nilainya menjadi pilihan.

Sebagian besar keputusan dalam organisasi sulit bahkan tidak dapat dipahami berdasarkan pilihan rasional yang sempit, dalam arti ketatnya karena keputusan sering menimbulkan ketidakpastian. Sebagaimana juga dikemukakan Wirawan (2013: 654) bahwa "pembuatan keputusan sering menghadapi situasi ketidakpastian, yaitu situasi di mana informasi 
mengenai alternatif tidak tersedia sehingga keluaran setiap alternatif sulit diperhitungkan. Termasuk dalam situasi ketidakpastian adalah jika semua alternatif yang ada tidak menguntungkan bagi pengambil keputusan. Dalam keadaan seperti ini, menghendaki agar pengambil keputusan dapat menganalisis alternatif yang paling kecil kerugiannya".

Manusia manapun tidak selalu mampu mengoreksi segala sesuatu dengan pilihan paling logis dan paling memuaskan, karena keterbatasan manusia. Hal tersebut tidak dapat diingkari, karena itu banyak keputusan paling baik dipahami berdasarkan pilihan bukan rasional sesuai kondisinya, tetapi manfaat dan efektivitas dari keputusan tersebut. Hasil penelitian menunjukkan bahwa Dekan sebagai pemimpin telah berupaya agar setiap keputusan dapat direalisasikan sesuai yang ditetapkan dan tujuan yang ingin dicapai. Tetapi dengan adanya kebijakan yang dikeluarkan pimpinan Universitas dengan berbagai permasalahan yang muncul secara tiba-tiba menyebabkan pemimpin berupaya untuk menyelesaikan persoalan melalui tindakan dengan menggunakan kewenangan diskresi untuk kepentingan banyak orang terutama bagi mahasiswa, seperti masalah terkait dengan penyelesaian studi, biaya studi, penerimahaan mahasiswa baru, jadwal perkuliahan, dan pelaksanaan ujian. Walaupun tidak jarang tindakan demikian menimbulkan kontroversial terutama dikalangan dosen maupun mahasiswa karena dianggap menganggu rencana kegiatan yang sudah ditetapkan, terutama mengganggu kelancaran proses belajar mengajar.

\section{B. Diskresi}

Diskresi sangat terkait dengan kewajiban, tugas-tugas dan fungsi pemerintah dalam negara hukum modern dengan mengupayakan kesejahteraan masyarakat melalui pelayanan publik. Untuk menyelenggarakan tugas pelayanan publik, maka kepada pemerintah diberi kebebasan atau kemerdekaan bertindak untuk menyelesaikan masalah-masalah konkret yang memerlukan penanganan secepatnya dan belum ada aturannya. Sebagai upaya untuk melaksanakan pelayanan publik dan untuk memperlancar tugas dan tanggungjawab pemerintah yang sangat kompleks, konsekuensinya semakin banyak pula tindakan pemerintah/administrasi negara yang dituangkan dalam bentuk diskresi. Tindakan diskresi pejabat pemerintah tidak semuanya terselenggara sesuai dengan maksud dan tujuan pemberian diskresi kepada pemerintah. Banyaknya penggunaan diskresi yang didasarkan pada kebebasan bertindak oleh pejabat dalam menyelesaikan permasalahan nyatanya tidak semua diterapkan sesuai dengan peraturan kebijakan yang ada. Penggunaan diskresi oleh pejabat/pemimpin publik dengan alasan kepentingan publik ternyata juga mengorbankan orang lain. Keadaan ini juga masih nampak dilingkungan Universitas Negeri Manado khususnya pada Fakultas Ilmu Sosial.

Adanya peraturan kebijakan yang dikeluarkan pimpinan tingkat Universitas terkait dengan program-program yang ada, dan seringnya mengambil tindakan yang sifatnya diskresi ternyata tidak selamanya memberi dampak positif. Peraturan Kebijakan yang dikeluarkan Rektor antara lain dengan memperpanjang waktu pembayaran Uang Kuliah Tunggal (UKT), pada satu pihak sangat membantu (mahasiswa) yang terancam gagal karena belum memenuhi kewajibannya, tetapi di pihak lain menimbulkan dampak negatif karena dianggap pimpinan tidak konsekuen dengan peraturan, tidak tegas, bahkan tidak memiliki perencanaan yang matang. Kondisi ini menimbulkan sikap apatis, pandang enteng sehingga berdampak pada penegakan disiplin bagi mahasiswa maupun dosen,yang pada akhirnya berpengaruh pada efektivitas dan kualitas perkuliahan.

Diskresi sejatinya dimaksudkan untuk menyelesaikan permasalahan yang dihadapi pemerintah untuk menjawab ekspektasi masyarakat dalam rangka peningkatan kesejahteraan masyarakat melalui pelayanan publik. Tetapi dalam prakteknya berpotensi 
menimbulkan kerugian bagi orang lain. Thoha (2014: 80) menegaskan bahwa diskresi dan kekuasaan yang menyimpang bukan hakekat asli dari pemahaman dan pengamalan diskresi dan kekuasaan.

Tindakan diskresi merupakan tindakan pemerintah dalam rangka penyelenggaran kepentingan publik yang konkret, yang sifatnya sangat mendesak, yang penggunaaannya harus dapat dipertanggungjawabkan. Menurut Darumurti (2012:10) bahwa "diskresi merupakan pengecualian atas asas legalitas dalam situasi yang sangat spesifik". Oleh sebab itu keputusan yang sifatnya diskresi harus memenuhi persyaratan suatu diskresi, sebagaimana harapan Undangundang Nomor 30 Tahun 2014 tentang Administrasi Pemerintahan Pasal 22 sampai dengan 32. Keputusan diskresi hanya dapat dilakukan dalam kondisi tertentu, mengesampingkan aturan yang sudah ditetapkan semula, dan dilakukan terutama untuk kepentingan banyak orang.

Dekan sebagai pemimpin dimungkinkan menggunakan kewenangan yang sifatnya diskresi (kebijaksanaan). Menggunakan diskresi adalah salah satu hak yang dimiliki pejabat pemerintahan. Dalam teori dikenal dengan kekuasaan diskresi (Discresionary Power). Kewenangan diskresi merupakan perluasan fungsi pemerintahan yang memberikan kebebasan bertindak bagi pemerintah. Kebebasan bertindak yang dimaksud bukanlah kebebasan tanpa batas. Pembatasan kewenangan diskresi pemerintah menurut Darumurti (2012: viii) merupakan keharusan sebagai jaminan bagi dasar legitimasi seluruh warga negara, dan pertanggungjawaban merupakan konsekuensi semestinya dari asas the rule of law.

Kewenangan diskresi dimaksudkan untuk memberi ruang gerak kepada pejabat/pemerintah tetapi tetap berada pada koridor peraturan perundangan yang berlaku sebagai upaya untuk mencari solusi terhadap berbagai permasalahan pemerintah serta untuk menjawab tuntutan dan ekspektasi dari masyarakat terutama ketika ada permasalahan yang muncul dan belum ada aturannya. Dalam perspektif yuridis, kewenangan diskresi ini ditempuh karena kurang memadainya regulasi untuk diimplementasikan oleh pemerintah, tetapi juga harus diperhatikan bahwa kewenangan ini tetap berada di bawah suatu sistem hukum (Rule of Law) dalam rangka mewujudkan good governance.

\section{KESIMPULAN}

Berdasarkan data hasil dan pembahasan penelitian maka dapat disimpilkan bahwa pengambilan keputusan Dekan sebagai pemimpin pada dasarnya melalui:

1. Tahapan proses pengambilan keputusan, yaitu tahap: a) mengidentifikasi dan menganalisis permasalahan; b) mengidentifikasi alternatif dan solusi pemecahan masalah; c) menganalisis dan mengevaluasi masing-masing alternatif solusi; d) memilih alternatif terbaik; e) melaksanakan keputusan; dan f) melakukan evaluasi.

2. Untuk mengatasi stagnasi dan dalam rangka kelancaran pelaksanaan tugas dan fungsinya, dekan sebagai pemimpin organisasi melakukan tindakan diskresi untuk kepentingan publik sebagai solusi terhadap permasalahan dalam rangka menjawab tuntutan dan ekspektasi masyarakat/mahasiswa.

\section{REFERENSI}

[1] Darumurti, D Krishna, Kekuasaan Diskresi Pemerintah, Citra Aditya Bakti, Bandung, 2014

[2] Djatmiko, Yayat Hayati, Perilaku Organisasi, Alfabeta, Bandung, 2008

[3] Dwiyanto, Agus, Mewujudkan Good Governance Melalui Pelayanan Publik, Gadjah Mada University Press, Yogyakarta, 2008

[4] Handayaningrat Soewarno, Pengantar Studdi Ilmu Administrasi dan Manajemen, Haji Masagung, Jakarta, 1993 
[5] Hicks Herbert. G dan G. Ray Gullet, Organisasi. Teori dan Tingkah Laku. Bina Aksara. Jakarta, 1987

[6] Ivancevich, John M dkk, Perilaku dan Manajemen Organisasi. Erlangga. Jakarta, 2008

[7] Luthans, Fred, Perilaku Organisasi. Ed. Sepuluh. Andi. Yogyakarta, 2006

[8] Miles, M.B \& Huberman, A.M, Analisis Data Kualkitatif. Buku Sumber Tentang Metode-metode Baru. Penerjemah: Tjetjep Rohendi Rohidi. UI. Press. Jakarta, 2007

[9] Simon A. Herbert, Admkinistrative Behavior. Perilaku Administrasi, Suatu Studi tentang Proses Pengambilan Keputusan dalam Organisasi Administrasi. Bina Aksara.Jakarta, 1982

[10] Sunyoto Danang dan Burhanudin, Teori Perilaku Keorganisasian. CAPS. Yogyakarta, 2015

[11] Thoha Miftah, Perilaku Organisasi. Konsep Dasar dan Aplikasinya. RajaGrafindo Persada. Jakarta, 2011

[12] -----------------, Birokrasi Pemerintah di Era Reformasi. Kencana Prenadamedia Group. Jakarta, 2014

[13] Winardi, Asas-asas`Manajemen. Mandar Maju. Bandung, 2010

[14] Wirawan, Kepemimpinan. Teori, Psikologi, Perilaku Organisasi, Aplikasi dan Penelitian.PT RjaGrafindo Persada. Jakarta, 2013

[15] Undang-Undang Nomor 30 Tahun 2014 Tentang Administrasi Pemerintahan. 2015. Biro Hukum, Komunikasi dan Informasi Publik Kementerian Pendayagunaan Aparatur Negara dan Reformasi Birokrasi 
Jurnal Kajian Kebijakan dan Ilmu Adminstrasi Negara (Jurnal ADMINISTRO)

http://ejournal.unima.ac.id/index.php/administro 